\title{
Santarém (PA): um caso de espaço metropolitano sob múltiplas determinações
}

\author{
Santarém (state of Pará): a case of metropolitan \\ space under multiple determinations
}

\author{
Taynara do Vale Gomes \\ Ana Cláudia Duarte Cardoso \\ Helder Santos Coelho \\ Kamila Diniz Oliveira
}

\begin{abstract}
Resumo
A região metropolitana de Santarém ilustra um padrão de metrópole em formação incomum, em que a diversidade socioespacial atende tanto ao perfil hegemônico metropolitano, quanto a origem amazônica ribeirinha. Este artigo expõe as coalizões criadas entre agentes econômicos do capitalismo global, elites locais e forças governamentais e o quanto as novas correlações de forças favorecem os interesses do setor imobiliário e financeiro, em detrimento da população local que historicamente tem sabido manejar seus espaços. As trajetórias das sedes de Santarém, Belterra e Mojuí dos Campos, quando contrapostas às centenas de assentamentos rurais, reafirmam as limitações da institucionalização oficial dessa região metropolitana, excluindo comunidades tradicionais e beneficiando grandes agentes capitalistas, além de desperdiçar potenciais de inovação em direção ao equilíbrio entre o meio urbano e o natural.
\end{abstract}

Palavras-chave: urbanização; Amazônia; diversidade socioespacial; Região Metropolitana de Santarém.

\begin{abstract}
The Metropolitan Region of Santarém illustrates an unusual metropolization pattern in which socio-spatial diversity satisfies both the metropolitan hegemonic profile and the Amazonian riverside origin. This article approaches coalitions created among economic agents of global capitalism, local elites and the public sector, and how the new correlation of forces favors the interests of the real estate and financial sectors, to the detriment of the local population, which, historically, has been wise in the management of their spaces. The trajectory of Santarém's, Belterra's, and Mojuí dos Campos' municipality seats, when opposed to hundreds of rural settlements, reaffirms the limitations of the official institutionalization of this metropolitan region, excluding traditional communities and benefitting large capitalist agents, wasting innovative potentials that head towards a balance between the urban and the natural environment.

Keyword: urbanization, Amazon, socio-spatial diversity, Metropolitan Region of Santarém.
\end{abstract}




\section{0 problema da urbanização e metropolização industriais na floresta}

Santarém é a cidade mais importante do oeste paraense. Ela teve sua fundação portuguesa há 355 anos, mas seu sítio teria sido ocupado há mais de dez mil anos. 0 lugar abrigou civilizações portadoras de dinâmicas urbanas, cultura e organização social próprias e serviu de nó para redes que conectavam populações de diferentes territórios da Amazônia, segundo evidências já apresentadas por autores ligados aos campos da Ecologia Humana e Antropologia Biológica (Neves, 1992). Registros de ocupações pré-cabralinas apresentados no trabalho da arqueóloga Anna Roosevelt (Roosevelt, 1992) - pinturas rupestres, artefatos cerâmicos, vestígios de organização espacial, além do manejo florestal e dos rios - são as evidências que dão suporte às estimativas de que a região tenha sido ocupada desde $11 \mathrm{mil}$ anos e seja reportada como uma das áreas de ocupação mais antiga de toda a América do Sul.

Apesar das frases de efeito do material publicitário usado para justificar a forma como ocorreu a integração econômica da Amazônia ao Brasil durante o governo militar - tais como a famosa "Terra sem homens para homens sem terra" - não teria havido efetivo vazio demográfico naquela região, mas sucessivas colonizações, sujeitas às ondas migratórias que modificaram as formas de ocupação do território e os modos de vida, além de geraram híbridos socioespaciais ainda pouco compreendidos, em face da ignorância de tais entrelaçamentos. Após décadas de desqualificação dos povos originários pelas vertentes hegemônicas da arqueologia (Leite, 2009), tornou-se mais fácil a conversão desse território à lógica capitalista e urbana-industrial. ${ }^{1}$

Nessa perspectiva, a missão jesuítica estabelecida em 1661 metabolizou a estratégia de ocupação indígena e metamorfoseou a aldeia tapajônica em vila portuguesa. Santarém foi elevada à categoria de vila em 1758, e cerca de um século depois (1848) se tornou cidade. A localização estratégica no ponto médio entre Belém e Manaus explica a importância que essa cidade ribeirinha e portuária assumiu durante o período de exploração da borracha, entre 1850 e 1910, e sua capacidade de sustentar 0 papel de capital regional posteriormente. Isto ocorreu graças à intensa migração de nordestinos para a Amazônia em fuga das grandes secas de 1915 e $1942^{2}$ (ver Figura 1) e à diversidade de produtos que alavancaram ciclos menores. Entre 1920 e 1960, o carro-chefe foi a produção de juta nas várzeas próximas e, entre 1950 e 1970, a exploração de ouro 3 em garimpos que se estenderam até Itaituba e sustentaram as funções já consolidadas em Santarém. Mas, de modo menos perceptível, a ação do caboclo extrativista, camponês convertido ao extrativismo, dos índios urbanos e quilombolas foi subjacente à identidade cultural da região, baseada no manejo bem-sucedido dos recursos naturais para o sustento da família, e não para acumulação. ${ }^{4}$

A partir de 1960, obras de infraestrutura provocaram grandes mudanças, alterando radicalmente as condições de acesso e produção (implantação de aeroporto, rodovias, construção de hidrelétrica, porto, etc.) que culminaram na atual integração da região ao eixo de exportação e produção de soja. A visão geopolítica para a Amazônia, concebida no âmbito dos I e 
Figura 1 - Material de divulgação oficial utilizados durante o Estado Novo para atrair nordestinos para a Amazônia

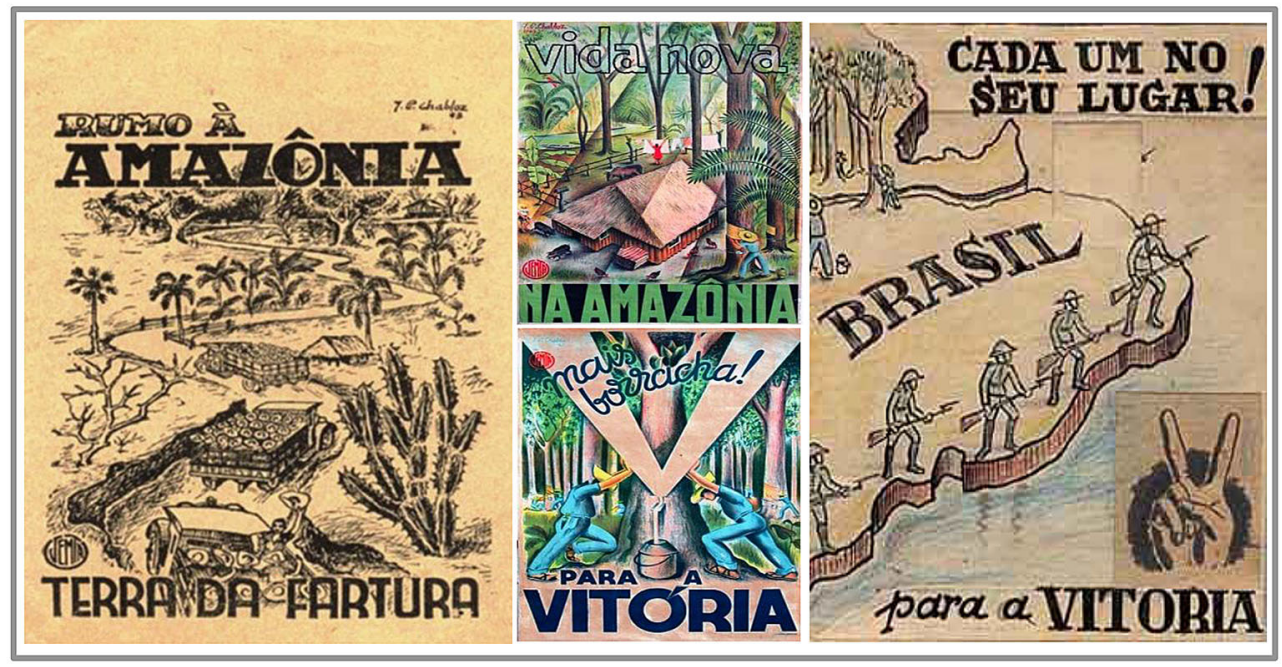

Fonte: http://www.rondoniaovivo.com/noticia/soldados-da-borracha-a-propaganda-do-dip-e-o-pintor-suico-que-ajudou-a-persuadir-nordestinos-a-virem-para-a-amazonia/90534. Acesso em: 16 mar 2017.

II Planos de Desenvolvimento Nacional na escala macro (global), tinha foco na produção extrativa mineral e na agricultura (Tavares, 1986) e nenhum compromisso com as esferas de vida intermediária e cotidiana, intrínsecas para a compreensão do processo de urbanização em sua totalidade (Lefebvre, 2008).

0 território amazônico teria sido integrado à matriz produtiva industrial, por meio de um processo de urbanização extensiva, ${ }^{5}$ conforme descrito por Monte-Mór (1994) em suporte à política de substituição de importações do País, como uma espécie de "almoxarifado". Sua população original (indígenas, ribeirinhos, caboclos, quilombolas, etc.) foi facilmente mantida invisível, uma vez que o controle do território por tais populações era feito pela posse e efetivo trabalho no território, enquanto as políticas federais pressupunham a propriedade privada da terra e o incentivo à produção por meio de crédito bancário. A nova lógica era direcionada para a atração do capitalista pioneiro, oriundo do centro-sul, movido pelo sonho do enriquecimento rápido, graças à facilidade de acúmulo de terras, de exploração de madeira e do crédito para pecuária (ver Figura 2). Diferentemente do migrante nordestino, esse novo pioneiro contou com meios para introduzir suas próprias formas de produção na região e não se adaptou às práticas anteriores. Aspectos sociológicos, econômicos e políticos - que extrapolam o escopo deste artigo - geraram uma nova elite, interessada na produção dirigida para o consumo das sociedades industriais. 
Figura 2 - Material publicitário adotado pelo governo federal durante o regime militar para atrair "pioneiros" para a Amazônia

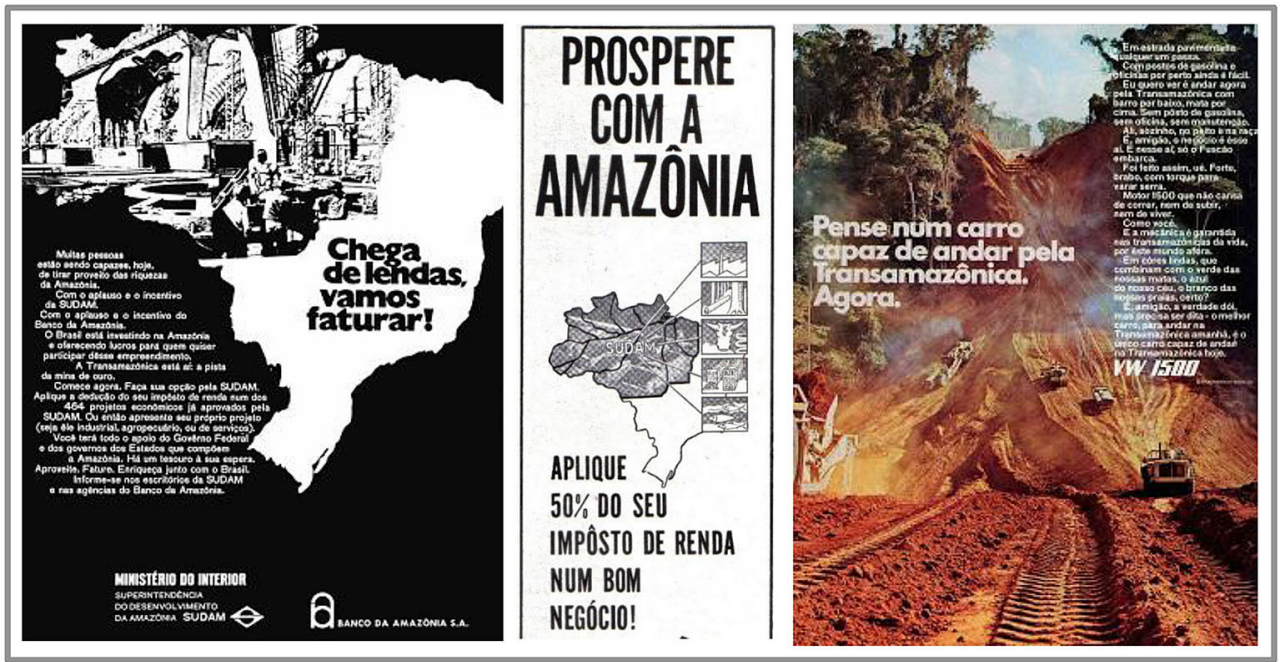

Fonte:http://candidoneto.blogspot.com.br/2009/04/chega-de-lendas-vamos-faturar.html. Acesso em: 16 mar 2017.

Contudo, todas as transformações nas condições de produção não resultaram no assalariamento ou na universalização do acesso da população local à renda, gerando na prática superposições e conflitos entre visões e formas de relacionamento com o território e com a natureza. Em um extremo, emergiu o interesse pelo fortalecimento das funções da cidade e da reestruturação do espaço regional e de criação de uma nova região metropolitana, para exercer papeis típicos das antigas metrópoles - 0 controle econômico da sua área de influência, a difusão de novos valores (urbano-industriais) na sociedade local e a articulação como centros de comando localizados em outras regiões do País ou internacionais - que, via de regra, demandam produtos que dependem de controle, destruição ou exaustão da natureza.
No outro extremo, é visível a resistência da população "invisível", que mantém suas formas de vida e sustenta traços de identidade importantes, traduzidos em arranjos produtivos e em alternativas de viver, produzir e preservar historicamente bem-sucedidas, mas que dependem da natureza viva.

Contra esse pano de fundo, este artigo espera tecer considerações sobre o significado da criação da região metropolitana de Santarém e o surgimento de um novo padrão de metrópole, herdeira da logística e dos dividendos da exportação de commodities, paraíso da acumulação primitiva para o setor imobiliário articulado globalmente, mas palco de profundas desigualdades, violências e conflitos contra a população que sempre soube como usufruir e preservar seus tesouros. Espera-se com esse 
debate discutir alternativas para a cidade amazônica, aproveitando a literatura que aborda cidades boas para se viver nos países centrais, e expor o imperativo da interdisciplinaridade e do compromisso com a totalidade da vida, para a produção dessa e de outras regiões metropolitanas periféricas, em pleno século XXI.

\section{A metrópole do século XX versus a metrópole do século XXI}

A metrópole foi estabelecida como padrão de urbano e de cidade durante o século XX. Nesse século, as grandes metrópoles foram associadas ao processo de industrialização, gerador de aglomeração urbana e de precariedade social e ao de infraestrutura no ambiente intraurbano. 0 caos social das cidades industriais do século XIX foi enfrentado na virada do século XX por meio das intervenções higienistas, provisão de habitação e melhoria de mobilidade. 0 espaço construído foi gradativamente adaptado para facilitar a produção capitalista e a exploração da força de trabalho da população (Hall, 1995). Em sua narrativa da história do planejamento urbano, Hall (ibid.) relata as lutas por melhores condições de vida no início do século XX em cidades americanas e europeias e destaca que a ação oficial ocorreu em três frentes prioritárias - o enfrentamento dos problemas sociais, de saúde pública e da precariedade física. Até 1920 , os países centrais teriam resolvido os problemas de cunho social e de saúde pública, por meio de obras de saneamento e de instituições que estabilizaram as condições sociais, minimizando, assim, os danos causados pela revolução industrial no contexto das cidades. Após essa etapa, emergiu o foco da estética urbana e da qualidade da paisagem, tão importante nas fases recentes do capitalismo. As tecnologias de informações e de transporte impulsionaram a internacionalização e a diferenciação da experiência cotidiana dos grupos sociais pobres e ricos (Castells, 1999). As novas práticas de flexibilização do planejamento pós1970 favoreceram a superposição de estruturas privadas voltadas para o consumo (espaços de serviços) sobre os velhos espaços democráticos e públicos, e nas primeiras décadas do século XXI buscam solução para os diversos problemas da urbanização por subúrbios monofuncionais e para o distanciamento da natureza em manchas urbanas que artificializaram ou poluíram seus sítios, sob a égide da sustentabilidade (Hall, 1995 e Martinez, 2012).

No Brasil, a metrópole antecedeu à indústria. Em função da inserção periférica do Brasil na divisão social do trabalho, o sentido de urbano e de cidade tem sido diferente para os brasileiros em relação ao que tem sido para os europeus e norte-americanos. No Brasil, a cidade sempre foi um ponto de controle do Estado, para cobrança de impostos e garantia de soberania, e não contou com os estágios experimentados pela cidade europeia, de locus de ascensão da burguesia contra a aristocracia absolutista, especialmente após a industrialização.

Salvador e Rio de Janeiro são exemplos de cidades consolidadas antes da indústria se estabelecer no País. São Paulo foi a primeira cidade a se beneficiar da industrialização, e, ao conseguir associar poder econômico e político, assumiu o controle desse processo no País e, desde que se tornou uma cidade global, 
posicionou as demais cidades brasileiras (e suas áreas de influência) como suas periferias, manifestação no País do fenômeno descrito por Sassen (1988).

As cidades amazônicas que cresceram a partir dos grandes projetos e da política de integração nacional se consolidaram em uma fase da evolução capitalista que prescinde da estruturação das metrópoles clássicas, mas gera aglomerações e processos de periferização, sem a contrapartida da estruturação do espaço de produção e de reprodução da vida. Os problemas da moradia, do saneamento e da mobilidade ainda não foram sequer compreendidos de modo compatível com as demandas sociais e ambientais existentes.

0 padrão de urbanização hegemônico brasileiro segue reproduzindo uma trajetória defasada do modo de pensar a cidade, baseada ainda nas práticas do século XX. Segue a agenda dos processos especulativos, na mobilidade baseada no veículo motorizado individual, na verticalização, nas demandas da financeirização por introdução de tipologias homogeneizantes, tais como o shopping center, os projetos de orla e a canalização dos rios urbanos.

Nas cidades amazônicas, esse padrão de urbanização revela-se cada vez mais excludente, baseado em um discurso de "cidade oficial" que nunca existiu na região. Tais importações de tipologias e padrões do chamado "primeiro mundo" são reproduzidas em uma pequena parcela da cidade para o atendimento de grupos sociais específicos (migrantes e elites locais) e consomem os poucos recursos públicos disponíveis, muitas vezes eliminando recursos que são do interesse da maioria da população, que sabe como viver na região mesmo à margem do sistema capitalista. Ao eliminar a floresta, contaminar as águas, privatizar as orlas, o "planejamento" homogeneizante gera desigualdades e conflitos. Esse padrão de urbanização que, segundo Maricato (2001) e Santos (2013), é incompleto e excludente se reproduz e desterritorializa habitantes urbanos, periurbanos ${ }^{6}$ e rurais, substituindo-os pelo investidor, pelo turista ou pelo próspero morador de final de semana.

Tal gentrificação faz com que a questão habitacional do excluído seja resolvida a partir da ocupação improvisada de áreas de risco (em Santarém, áreas de várzeas e áreas inundáveis) e a combinação de adensamento, falta de saneamento e serviços de infraestrutura básica se tornem habituais. Desde os anos 1980, esse quadro extrapolou o universo das grandes cidades da costa litorânea e passou a se manifestar nas cidades que desempenham funções de relevância regional, como é o caso de Santarém.

Contudo, os princípios urbanísticos disseminados pela metrópole do século XX priorizam aspectos econômicos na modelagem do espaço e homogeneízam valores culturais, assemelhando-se em certa medida às metrópoles americanas, europeias, asiáticas e latino-americanas. $A$ associação da metrópole com a prosperidade no século XX tornou-a locus da sociedade industrial e lugar da vida moderna. Na origem, ofereceu condições territoriais para a instalação da grande indústria, organização de um mercado consumidor e alojamento de uma nova classe a trabalhadora. Após as transformações recentes do capitalismo, a metrópole teve sua própria produção transformada em estratégia de reprodução do capital, ampliando o consumo de terras em processos de expansão urbana especulativos e implodindo as áreas já consolidadas, 
repaginadas para atenderem ao léxico urbanístico contemporâneo (Carlos, 2015).

Seguindo esse "impulso renovador" e 0 desejo cada vez maior de modernização, a metrópole do século XX surge como a materialização desses novos padrões e se beneficia da urbanização da sociedade e das novas formas de produção, distribuição, relações sociais e consumo. 0 século XX foi marcado pela crescente concentração de pessoas nas cidades, um constante aumento no índice de consumo e pela generalização do uso do automóvel. Outro fator característico dessa concepção de cidade foi uma urbanização responsiva à indústria, que assumiu a natureza como um produto a ser consumido (Harvey, 2016).

0 progressivo questionamento dessas práticas nos países do norte global ou da produção da cidade para produção, consumo e lucro tem tensionado esse paradigma e indicado a necessidade de uma nova agenda para as cidades. A dimensão humana e coletiva passou a ser valorizada; e conceitos como cidade viva, sustentável, saudável passaram a fazer parte do repertório das novas intervenções. Nesses países, a qualidade urbana tornou-se prioridade, como demostram as experiências recentes de Copenhagen ou Madri, ou o debate sobre Urban Design Codes, cidades compactas ou cidades criativas por todo o norte global (Haas et al., 2012). Na França, podemos destacar 0 surgimento de formas de gestão ambiental que incluem a Trame Verte et Bleu que busca articular espaços verdes de todo tipo às bacias hidrográficas de forma integrada com a malha urbana, malhas utilizadas para garantir saneamento, recuperação de solo, ar e água (Menerault, 2014 e Euclydes, 2016) e preservação de identidade cultural.
Aspectos da cidade do capital foram, mesmo que aos poucos, colocados em xeque. No século XXI, no contexto do Norte Global, entende-se que, além de atender às demandas do mercado, as cidades precisam atender às necessidades plurais dos seus moradores. Nesse sentido, modos de vida alternativos ao urbano industrial, que não dependem da lógica espoliativa das relações de trabalho, começam a ter mais visibilidade. E precisamente nesse ponto o que elites locais consideram atraso em Santarém revela-se como potencial de vanguarda. As comunidades existentes na área de expansão de Santarém, que são detentoras dos seus meios de produção e cuja terra é objeto de gestão coletiva, destacam-se pelo compromisso de garantir a reprodução coletiva da vida, ao invés de maximizar a produção.

Apesar de o sistema capitalista industrial ter se tornado hegemônico nas cidades brasileiras no século $X X$, ainda que segundo uma lógica periférica, ele não foi capaz de converter completamente as cidades amazônicas, em que pese o fato de a floresta já ser urbanizada desde a década de 1990 (Becker, 1998). Em face dos arranjos existentes, nesse contexto ainda há potencial para criação de uma trajetória diferente de cidade. As manifestações dos mesmos processos de periferização e exclusão em Santarém convivem com arranjos socioespaciais remanescentes de outros períodos, graças à força dos movimentos sociais rurais, apoiados por organizações não governamentais e por setores do governo federal comprometidos com a preservação ambiental - caso dos assentamentos agroextrativistas, reservas extrativistas e outras modalidades de assentamentos rurais implantados na região - que definem institucionalidades que garantiram a permanência 
de grupos originais em áreas periurbanas por décadas após a integração econômica e espacial da região, mas que agora são reclamadas pela especulação imobiliária (Emater, 2011 e Famceef, 2007).

A coexistência de modos de vida e práticas tradicionais com as intervenções modernizadoras indica que ainda há tempo para que pequenas e médias cidades da região se beneficiem dos acertos e erros praticados nas cidades do mundo, especialmente em um contexto de mudanças climáticas e de reconhecimento da importância de valores/saberes ambientais e sociais (que na região são milenares), recuperando o repertório endógeno e desenvolvendo novas formas de gestão territorial.

Observa-se que a riqueza de sociobiodiversidade da região é inversamente proporcional às limitações institucionais e econômicas existentes, demandando regras inovadoras para a gestão das cidades e dos territórios urbanos, periurbanos e rurais, todos completamente afetados pela ordem distante. Nesse sentido, se, por um lado, Santarém é exemplo de grande potencial de aderência às premissas contemporâneas para as cidades do século XXI, graças à diversidade de atributos espaciais, recursos naturais, sociodiversidade e qualidades ambientais, compatíveis com o que vem sendo perseguido nos países centrais em resposta à demanda por qualidade de vida urbana; por outro lado observa-se que todas as iniciativas indicam precisamente a direção contrária, com tendência de destruição da diversidade social e dos recursos ambientais por processos especulativos comandados por outras regiões e por outros países. É cada vez maior a pressão das elites locais articuladas com interesses externos pela reprodução das fórmulas difundidas no século anterior e pela homogeneização do território voltado para produção e consumo.

\section{Os espaços instrumentais da acumulação: da metrópole à cidade média}

0 processo de urbanização se intensificou no Brasil nos anos 1970. Na virada da década de 1960 para a de 1970,55,9\% da população do país era urbana; percentual que na região Sudeste já alcançava os $72,7 \%$ da população. Os fenômenos de conurbação e aglomeração urbana e o recorrente transbordamento de problemas das cidades-polo (via de regra, capitais) para suas periferias levaram o governo a instituir as primeiras regiões metropolitanas do País através da do parágrafo 10 do art. 157, da Constituição de 1967 (Garson, 2009). Nessa fase, o padrão de acumulação baseado na industrialização demandava a aglomeração ora institucionalizada nas regiões metropolitanas.

A partir de então, o planejamento e a administração de obras e serviços de interesse comum (saneamento básico, transportes, sistema viário e recursos hídricos) ficariam a cargo de uma entidade metropolitana, organizada pelo governo estadual e dirigida por um conselho metropolitano e por uma diretoria executiva que, em face do contexto autoritário (prefeitos indicados, ausência de participação popular), privilegiavam a adaptação das cidades às novas funções de produção. Tal sistemática foi alterada pela Constituição de 1988, que delegou aos estados a responsabilidade 
pela criação das regiões metropolitanas sem a contrapartida de oferta de mecanismos institucionais que permitissem construir esquemas de governança para uma nova gestão metropolitana (ibid.). As alterações no padrão de acumulação capitalista, com o declínio da indústria e o retorno às atividades primário-exportadoras (agronegócio, extrativismo mineral), reduziram a importância das grandes aglomerações desde então.

Nesse sentido, Costa e Tsukumo (2013) explicam que, para entender o processo de metropolização brasileiro, há necessidade de se distinguir metrópole de região metropolitana. Os autores definem metrópole como um processo socioespacial e de conformação do espaço que é percebido como comum por uma população que compartilha recursos, infraestrutura, serviços e possibilidades (p. 327); e região metropolitana como a instituição de ordem jurídico-institucional, que pode tratar, intervir ou gerir essa nova territorialidade, a qual pode ou não, integral ou parcialmente, corresponder a um espaço metropolitano resultante de um processo socioespacial (Castello Branco et al., 2013).

A partir da mudança constitucional de 1988, houve uma separação progressiva entre esses dois fenômenos - as metrópoles e as regiões metropolitanas (RMs) - propiciando grandes questionamentos sobre os critérios para a instituição dessas regiões, que atualmente somam mais de 50 no Brasil, enquanto os espaços de fato metropolitanos não acompanham esse mesmo crescimento. Tal fenômeno coloca em xeque o próprio sentido da necessidade dessa institucionalização (Costa e Tsukumo, 2013).
A dificuldade de compreensão imediata dos processos econômicos levou estados e municípios a crerem que a instituição de regiões metropolitanas seria uma alavanca de desenvolvimento, já que, a partir dessa institucionalidade, os municípios tornavam-se elegíveis para receber investimentos federais diferenciados. A tendência de desarticulação entre aspectos jurídicos e processos econômicos pode ser observada claramente na divergência de critérios para criação de RMs detectadas por estudos do final dos anos 1960, prévios à lei complementar n. 14/1973 e, em 2013, prévios à lei n. 13.089/2015, chamada de Estatuto da Metrópole, exposta no Quadro 1, que mostra que os parâmetros de movimento pendular, percentual de população ocupada na indústria e indicadores de comunicação entre os municípios-polo e periféricos já não são relevantes.

A metrópole consagrada como expressão máxima da fase industrial pressupunha a concentração de oportunidades de emprego e de acesso a serviços em um único centro, contudo, com a tendência de as cidades reelaborarem suas estratégias de controle do território no sentido de transcenderem o espaço, tem ocorrido uma redução da importância do espaço metropolitano e a emergência de uma demanda por novos padrões de urbanização mais funcionais aos novos padrões de acumulação capitalista.

A esse respeito, desde o final dos anos 1980, estaria em curso a transição do padrão industrial para o primário-exportador, período em que a economia do País passou a depender da exportação de commodities - grãos, carne, minério -, e as formas de apropriação do território tendem a mudar com a emergência 


\section{Quadro 1 - Critérios de delimitação de regiões metropolitanas propostos por Galvão et al. (1969) e por Ipea (2013)}

\begin{tabular}{|c|c|c|}
\hline Dimensão & Estudo de Galvão et al. (1969) & Estudo do Ipea (2013) \\
\hline \multirow{4}{*}{ Demográfica } & 1) População municipal de pelo menos 400 mil habitantes & Mantido \\
\hline & 2) Densidade do distrito-sede de pelo menos 500 hab. $/ \mathrm{km}^{2}$ & Mantido \\
\hline & 3) Densidade municipal de pelo menos $60 \mathrm{hab} . / \mathrm{km}^{2}$ & Mantido \\
\hline & $\begin{array}{l}\text { 4) Variação da população do decênio anterior deve ser de, no mínimo } \\
45 \% \text {, no município ou em um distrito contíguo. }\end{array}$ & Descartado \\
\hline \multirow{3}{*}{ Estrutural } & $\begin{array}{l}\text { 1) Pelo menos } 10 \% \text { da população potencialmente ativa do município } \\
\text { ocupada em atividades industriais }\end{array}$ & $\begin{array}{l}\text { Pelo menos } 70 \% \text { da sua população } \\
\text { ocupada em atividades urbanas }\end{array}$ \\
\hline & $\begin{array}{l}\text { 2) No caso dos chamados núcleos "dormitórios", essa porcentagem } \\
\text { é substituída por um índice de movimento pendular, igual ou superior } \\
\text { a } 20 \% \text { da população, deslocando-se diariamente para qualquer } \\
\text { município da área }\end{array}$ & Descartado \\
\hline & $\begin{array}{l}\text { 3) Quando o valor da produção industrial municipal for três vezes } \\
\text { maior que o da agrícola }\end{array}$ & Descartado \\
\hline \multirow{2}{*}{ Integração } & $\begin{array}{l}\text { 1) Pelo menos } 10 \% \text { da população municipal total deslocando-se } \\
\text { diariamente, em viagens intermunicipais, para qualquer município da } \\
\text { área (considerando fluxos de entrada e de saída do município). }\end{array}$ & Mantido \\
\hline & $\begin{array}{l}\text { 2) Quando tiver um índice de ligações telefônicas para a cidade } \\
\text { central superior a oitenta, por aparelho, durante um ano. }\end{array}$ & $\begin{array}{l}\text { Descartado por indisponibilidade } \\
\text { de dados }\end{array}$ \\
\hline
\end{tabular}

Elaboração: autores, em 2017.

\section{Quadro 2 - Mudanças decorrentes da transição do padrão de acumulação na região de Santarém e seus impactos no território e rede urbana}

\begin{tabular}{|l|l|l|l|}
\hline Padrão de acumulação & Mercantil & Industrial & Primário-exportador \\
\hline Base econômica & Extrativismo & Indústria & Extrativismo \\
\hline Negócio & Borracha, Juta, Ouro & Infraestrutura logística & Agronegócio \\
\hline Padrão de ocupação & Dispersão & Aglomeração & Dispersão \\
\hline Principal apoio na rede urbana & Cidade primaz (rede dendrítica) & Metrópole & Cidades Médias \\
\hline
\end{tabular}

Elaboração: autores, em 2017. 
das cidades médias como espaços especializados para a operação dessas "novas" atividades econômicas. 0 Quadro 2 recorre a um recorte temporal que alcança uma fase primária exportadora anterior (da colonização regional ocorrida dentro do boom da borracha), para mostrar esquematicamente como esse processo se aplica ao espaço regional de Santarém.

0 primeiro ciclo de economia primário-exportadora correspondia a um padrão de acumulação do capital mercantil e apoiava-se em uma rede urbana dendrítica, na qual Belém polarizava toda a região e concentrava os excedentes, a política e as elites da região, e as demais cidades eram mantidas pequenas e dependentes do extrativismo local. A chegada do urbano-industrial na região criou ilhas de modernidade articuladas internamente pelos projetos de integração nacional. Nesse novo padrão, foi constituída uma rede urbana com mais níveis hierárquicos, mas que consolidam as antigas cidades primazes como as metrópoles amazônicas a partir dos anos 1970.

As mudanças no padrão de acumulação ocorridas durante os anos 1990 levaram a novas mudanças territoriais; perda de indústrias e retorno a uma nova versão de economia primário-exportadora, não mais mercantil, mas conduzida por capital na sua forma industrial. Esse novo padrão primário-exportador não tem mais a necessidade de concentrar serviços e pessoas e destaca as cidades médias como novo locus da vida urbana. Essa nova urbanização extensiva integrou lugares desconectados espacialmente, transformando as cidades coloniais de matriz ribeirinha nos pontos de apoio imediato das novas atividades exportadoras.
Após anos de intervenções e políticas de colonização, novas identidades foram construídas, majoritariamente a partir do poder hegemônico de oligarquias que se apropriaram das oportunidades de modernização para se reinventar. Décadas de grandes investimentos em infraestrutura logística próxima a cidades ribeirinhas as transformaram em polos regionais (casos de Santarém, Marabá, Tucurui, Altamira, etc.) e geraram a expectativa de subdivisão do território estadual e de criação de novas regiões metropolitanas nas cidades que seriam as capitais desses novos estados, conforme pode ser observado na Figura 3. Observe-se que tal proposta não foi aprovada em plebiscito estadual realizado em 2011, por fatores que extrapolam o escopo deste artigo.

A institucionalização desse novo tipo de RM tem sido possível graças às mudanças no padrão de acumulação, mas aparenta alimentar uma expectativa de reestabelecimento das antigas funções que a metrópole exercia na década de 1970. São comuns as tentativas de atração de plantas industriais para Santarém (beneficiamento de óleo de soja) e Marabá (siderúrgica) com negligência aos impactos socioambientais das propostas analisadas ou com as diferenças no potencial de geração de empregos que indústrias sob composições orgânicas do capital que prioriza o investimento massivo em equipamento oferecem em relação ao volume de empregos gerados nas metrópoles brasileiras dos anos 1970. $\mathrm{Na}$ nova versão, as atividades industriais desterritorializam população sem oferecer a possibilidade real de integração às novas dinâmicas econômicas. 
Figura 3 - Proposta de divisão do estado do Pará e de criação de novas regiões metropolitanas nas cidades que seriam as novas capitais estaduais

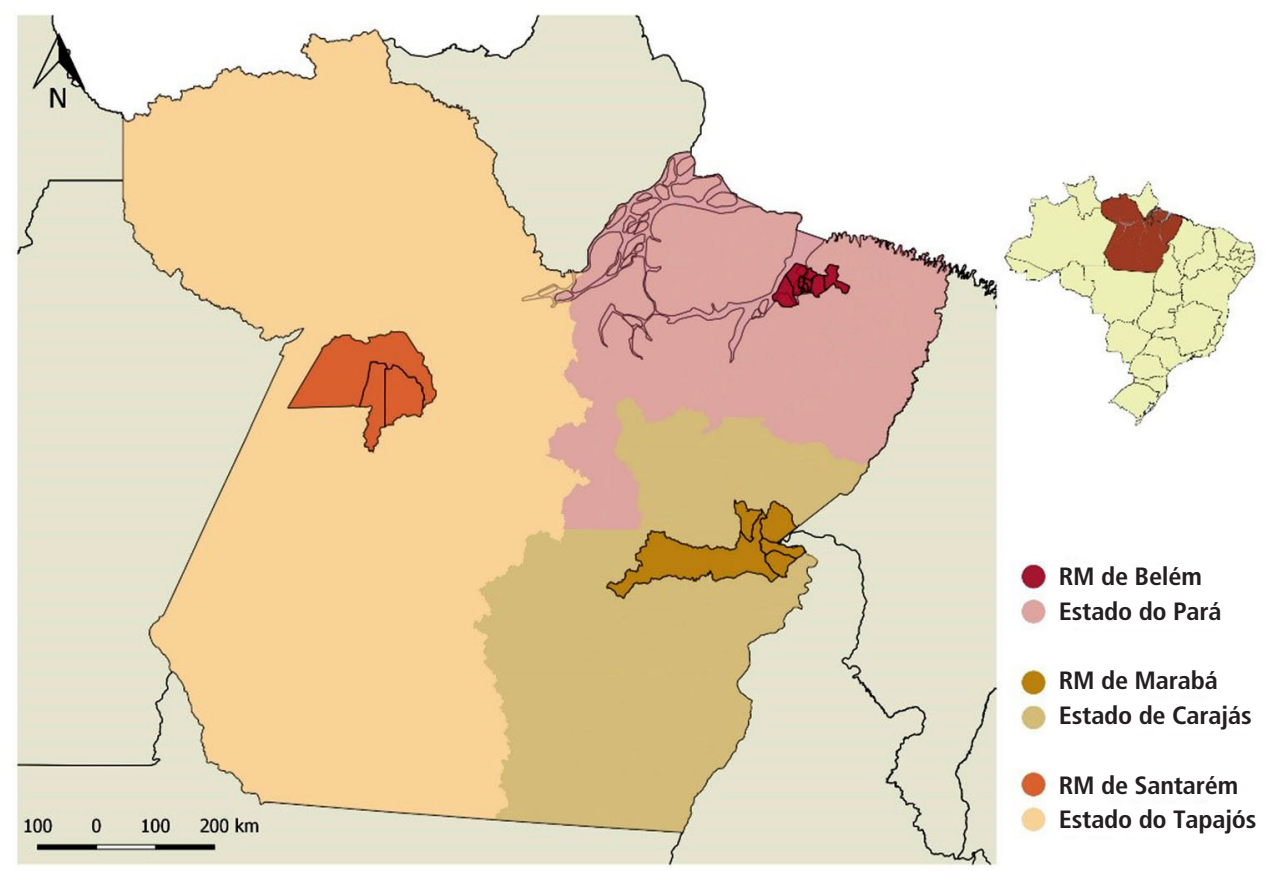

Fonte: IBGE, 2010. Elaboração: autores, em 2017.

Dito de outra forma, não há vínculo entre ocupação industrial, conurbação ou padrão de distribuição populacional condizente com metropolização, mas há expectativa de ampliação de mancha urbana e de alavancagem de desenvolvimento a partir da constituição das RMs, considerando os incentivos que foram dados aos polos nacionais e regionais constituídos nos anos 1970. As primeiras RMs receberam incentivos de fato ao mesmo tempo que estabeleceram seu domínio na rede de cidades do País e assumiram a liderança no desenvolvimento econômico brasileiro, em diálogo com o que foi proposto no II PND (Plano Nacional de Desenvolvimento) (Castello Branco et al., 2013). 


\section{A trajetória do território da região metropolitana de Santarém}

Como a economia da cidade sempre foi movida a partir do extrativismo de diversos ciclos de produtos, a ocupação do território manteve o padrão de dispersão, praticado desde fases pré-cabralinas, conforme indicam os estudos arqueológicos citados na introdução deste texto, e incorporado pelos portugueses por ocasião da implantação de vilas e missões religiosas na região. As derivações contemporâneas dessa distribuição histórica de população podem ser observadas na Figura 4, que contrapõe as localidades (vilas e comunidades), manchas urbanas das sedes municipais, extensão dos municípios e indicação da hidrografia, de modo a explicitar a determinação histórica de localização dos assentamentos humanos pelos rios. A abundante biodiversidade da Amazônia teria dado suporte para modos de vida harmônicos com a natureza, sociedades (indígenas, quilombolas e outras) que conseguirem estabelecer a produção e a reprodução da vida a

Figura 4 - Região metropolitana de Santarém: localidades versus manchas urbanas
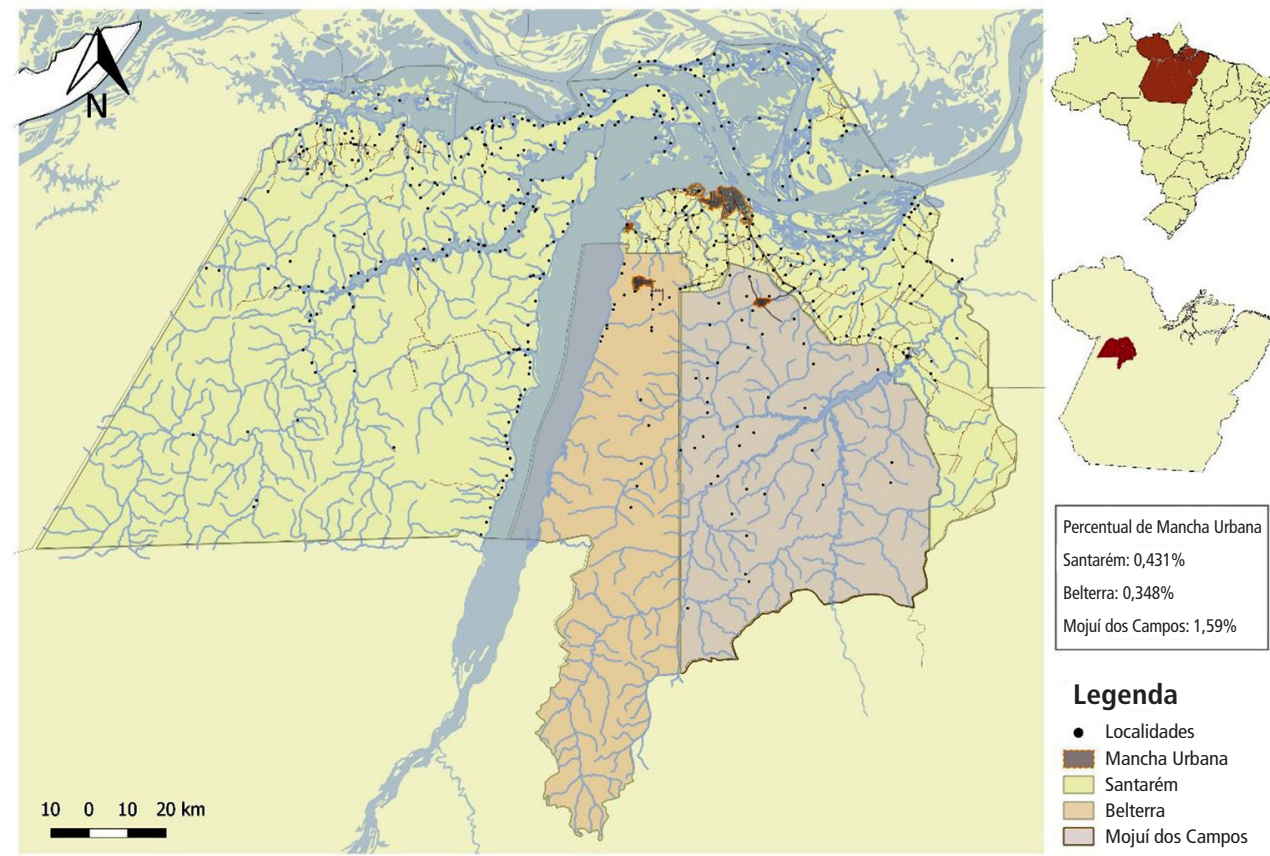

Fonte: IBGE, 2010; Google Earth, 2017; Sindicato dos trabalhadores rurais de Santarém (STTR), 2016. Elaboração: autores, em 2017. 
partir do manejo de recursos fornecidos pela natureza (extrativismo, pesca, caça, agricultura, abastecimento de água, uso da madeira para produção de casas e embarcações, etc.).

A implantação do modo de produção capitalista rompeu o vínculo entre homem e natureza e fez com que esta última deixasse de ser vista como suporte à subsistência da população e passasse a integrar o conjunto de meios de produção daquele sistema. A chegada da infraestrutura logística e de novos atores sociais levou a significativas mudanças socioeconômicas, políticas e tecnológicas, de forte viés colonizador, dessa vez pelos brasileiros oriundos de outras regiões, e gerou uma tensão entre as duas racionalidades superpostas a modernizante e a tradicional. A ação coordenada entre governo federal e setor privado resultou em imposições do mercado que aproveitaram a fraca ação governamental nas esferas da vida intermediária e cotidiana e atuaram de modo seletivo nas cidades e no meio rural, visando máximo atendimento dos interesses econômicos (com fraca capacidade de regulação, planejamento e investimento públicos) e nenhum respeito a mecanismos e estratégias territoriais já existentes. A visão colonizadora foi seletiva e priorizou as conversões necessárias para atender a ordem distante, a princípio estabelecida a partir do centro sul do País e, após os anos 1990, década de privatizações, deslocada para os grandes centros globais, demandantes das commodities que passaram a ser produzidas na região.

Nesse âmbito, prevaleceu a violência e o poder político e econômico, o que levou a reações conservacionistas desdobradas na política ambiental brasileira, mas que foram igualmente incapazes de compreender o relacionamento entre sociedade e natureza praticado ancestralmente na região, ao se pautarem em uma concepção de preservação baseada na delimitação de áreas intocáveis, por um lado, e liberação de todo o restante para exploração. Essa concepção de preservação também negou o modo de vida tradicional e impôs paradigmas metropolitanos de visão da natureza (como algo externo à vida ou como reserva de valor para exploração futura).

Décadas de atuação do movimento social e de organizações não governamentais promoveram inovações na política ambiental capazes de mediar os interesses das duas racionalidades. A aproximação de abordagens socioambientais permitiu a proposição de formas de assentamentos rural diferenciadas na região (assentamento agroextrativista, reserva extrativista, assentamento comunitário, entre outros) implantados pelo governo federal (por meio do Instituto Nacional de Colonização e Reforma Agrária - Incra) e pelo governo estadual (por meio do Instituto Estadual de Terras - Iterpa), graças ao reconhecimento de que o impacto do manejo de populações tradicionais é muito menor do que sua contribuição para a preservação de rios e florestas. Isso resultou na formação de um mosaico de áreas protegidas e tipologias de assentamento rural nos municípios em questão (Belterra e Mojuí foram emancipados de Santarém em 1997 e 2010 respectivamente, motivados pelas transformações desencadeadas pela implantação da BR 163 e pela Hidrelétrica Curuá-Una) que atualmente ocupa mais de $50 \%$ do território metropolitano (ver Figura 5).

Contudo, desde a elaboração do Plano Diretor de Santarém, em 2006, houve a definição de uma área de expansão urbana que 
Figura 5 - Arranjos institucionais que asseguram modos de vida tradicionais

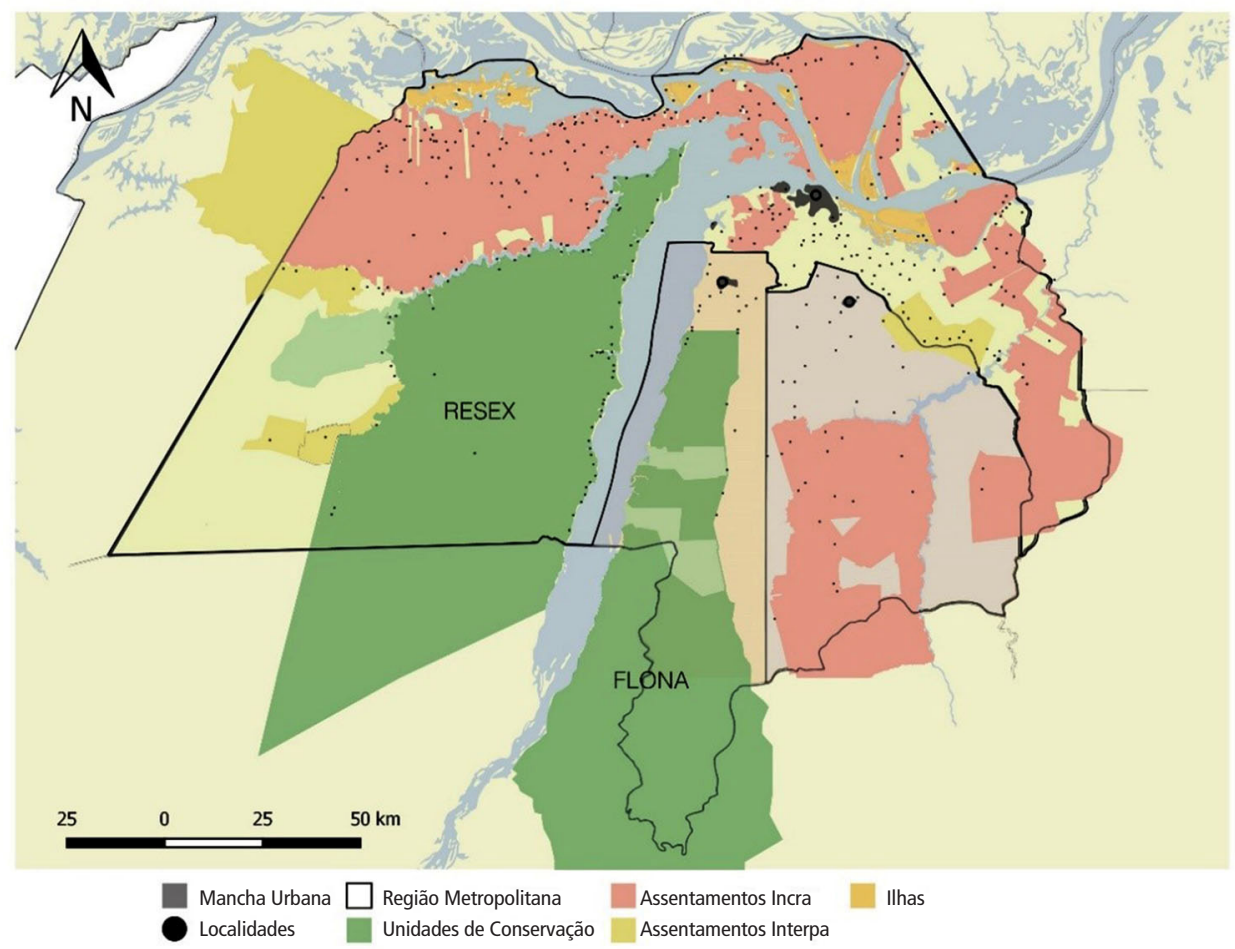

Fonte: IBGE, 2010; Google Earth, 2017; Sindicato dos trabalhadores rurais de Santarém (STTR), 2016.

Elaboração: autores, 2017.

alcançava a cidade de Belterra e o núcleo urbano de Mojuí dos Campos, definindo um raio de cerca de $30 \mathrm{~km}$ a partir do centro de Santarém (ver Figura 6). Esse espaço que era ocupado por produção familiar e passou a ser disputado pela monocultura da soja, conforme pode ser observado na Figura 7, e contém um próspero assentamento agroextrativista (Assentamento
Eixo Forte), que sofre pressão por parte da elite local para ser extinto, em função da disputa da sua localização pelo segmento imobiliário que passou a atuar recentemente em Santarém, que cobiça as terras localizadas entre Santarém e a famosa Vila de Alter do Chão e as vistas das paisagens exuberantes do Rio Tapajós (ver Quadro 3). 
Figura 6 - Mapa de zona de expansão urbana do Plano Diretor de Santarém

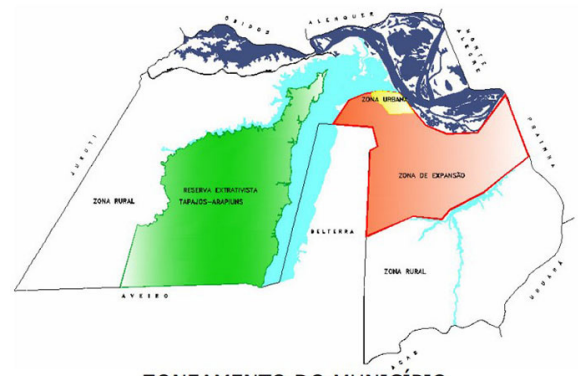

ZONEAMENTO DO MUNICÍPIO
Figura 7 -- Dinâmicas econômicas na RM de Santarém: eExtrativismo, agricultura familiar e monocultura da soja

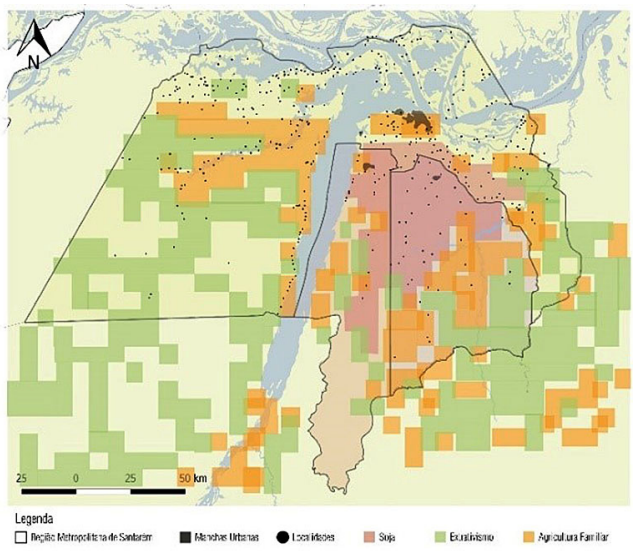

Fonte: IBGE, 2010; Google Earth, 2017; STTR, 2016; Souza, 2018. Elaboração: autores, 2017.

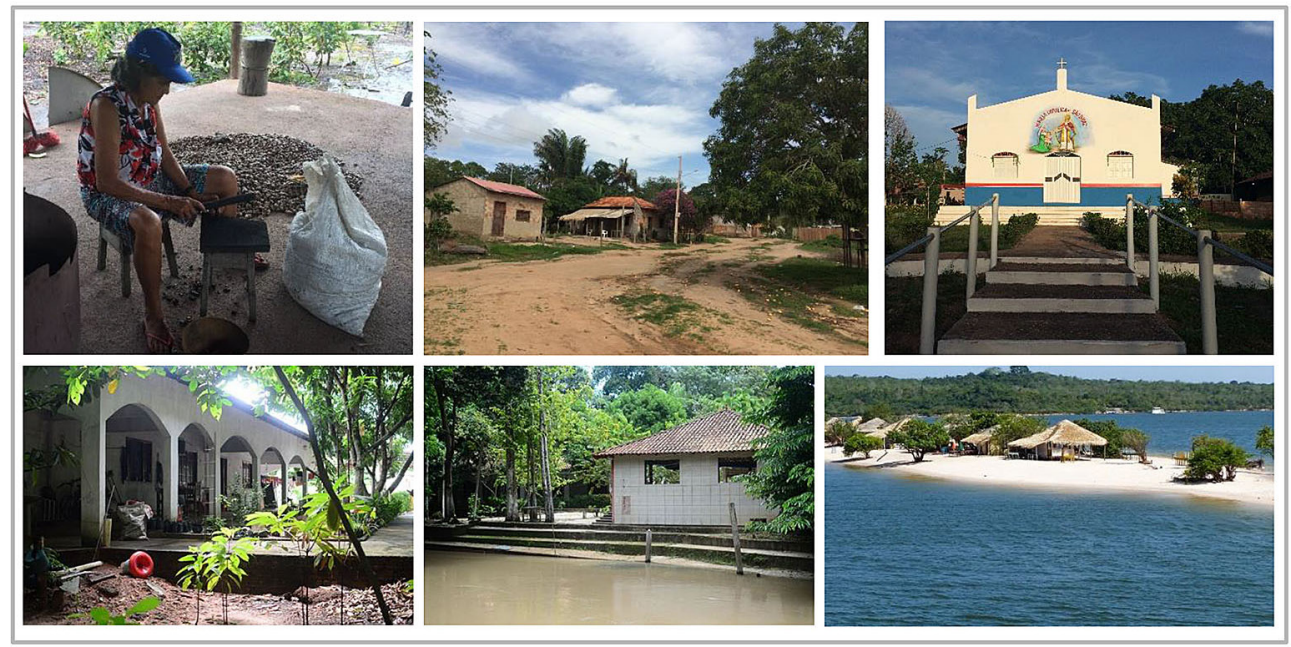

Elaboração: autores, 2017. 
A introdução da monocultura da soja, nos anos 2000, e da produção imobiliária, nos anos 2010, ressignificou o padrão tradicional de ocupação territorial, através da captura das antigas vilas por novos usos e formas de viver. A articulação dos pequenos núcleos por estradas permitiu a estratificação do espaço em gradientes de periferia urbana ou ocupação rural, que dependem do ponto de vista do observador. 0 migrante motorizado habituado às grandes distâncias passou a ocupar vilas e cidades menores, constituiu novos assentamentos (loteamentos de renda superior à média da população) autossegregados ${ }^{7}$ e agora migra para os novos empreendimentos imobiliários verticais, construídos no centro da cidade de Santarém, ou para novos loteamentos localizados na estrada do acesso ao aeroporto.

A produção de soja forçou o desmantelamento de comunidades rurais e a extinção de rotas de transporte público que atendiam aos pequenos produtores, inviabilizando a região para o antigo morador e facilitando a sua apropriação por novos usos e tipologias. Esse processo de explosão e dispersão de usos urbanos pelo território manifesta o fenômeno da urbanização extensiva (Monte-Mór, 2015), com destaque para a vinculação ao modo de vida urbano pelo consumo, também acompanhado pela implosão dos espaços consolidados (seja no centro urbano seja nas vilas). As transformações em curso nas duas sedes dos municípios que constituem a periferia metropolitana: Belterra - núcleo urbano construído para apoiar o produção de borracha sob iniciativa de Henri Ford, com ruas originalmente distantes de três em três quilômetro, e tipologia de edificações tipicamente norte-americanas - e Mojuí dos Campos - assentamento carente de todas as infraestruturas e inserido na miríade de assentamentos rurais reconhecidos pelo principal movimento social da região (como o Sindicato de Trabalhadores Rurais). A espacialidade das formas de uso e ocupação do território revela as mais diversas estratégias, praticadas pelos também diversos agentes produtores do espaço urbano, que buscam, a partir das condições concretas, defender seus interesses. A paisagem torna-se o resultado dessas múltiplas determinações e revela a sobreposição de manifestações da mundialização aos caminhos naturais e sociais que guardam dimensões e sentidos traçados em outras épocas (ver Quadro 4).

0 reduzido território coberto pelas manchas urbanas de Santarém, Belterra e Mojuí, quando contraposto às centenas de assentamentos rurais, herdeiros de comunidades tradicionais, indica o ainda frágil protagonismo urbano-industrial, viabilizado pela conexão criada pela infraestrutura logística da região aos circuitos globais - entre a lógica portuária e o agronegócio. Em paralelo a esse circuito superior (Santos, 1979), as comunidades continuam a reproduzir dinâmicas seculares e modos de vida extremamente bem adaptados e articulados com a natureza da região, ainda que sejam cada vez mais invisibilizados pelos interesses das frações do capital industrial e financeiro que esperam gradativamente se apropriar do território a partir das novas formas de coalizão entre setor público e privado observadas no País. ${ }^{8}$

Atualmente, o espaço contido na RM Santarém é ambivalente: atende ao perfil hegemônico de metrópole, incorporando as tipologias correntes do léxico da cidade global - shopping center, projeto de orla típico, pressão por verticalização, loteamentos de 
Quadro 4 - Diferentes formas de apropriação do espaço da orla da cidade de Santarém. Observar gradiente entre o porto da Cargill (exportador), o porto de passageiros (regional), a orla urbanizada e a orla natural e histórica.
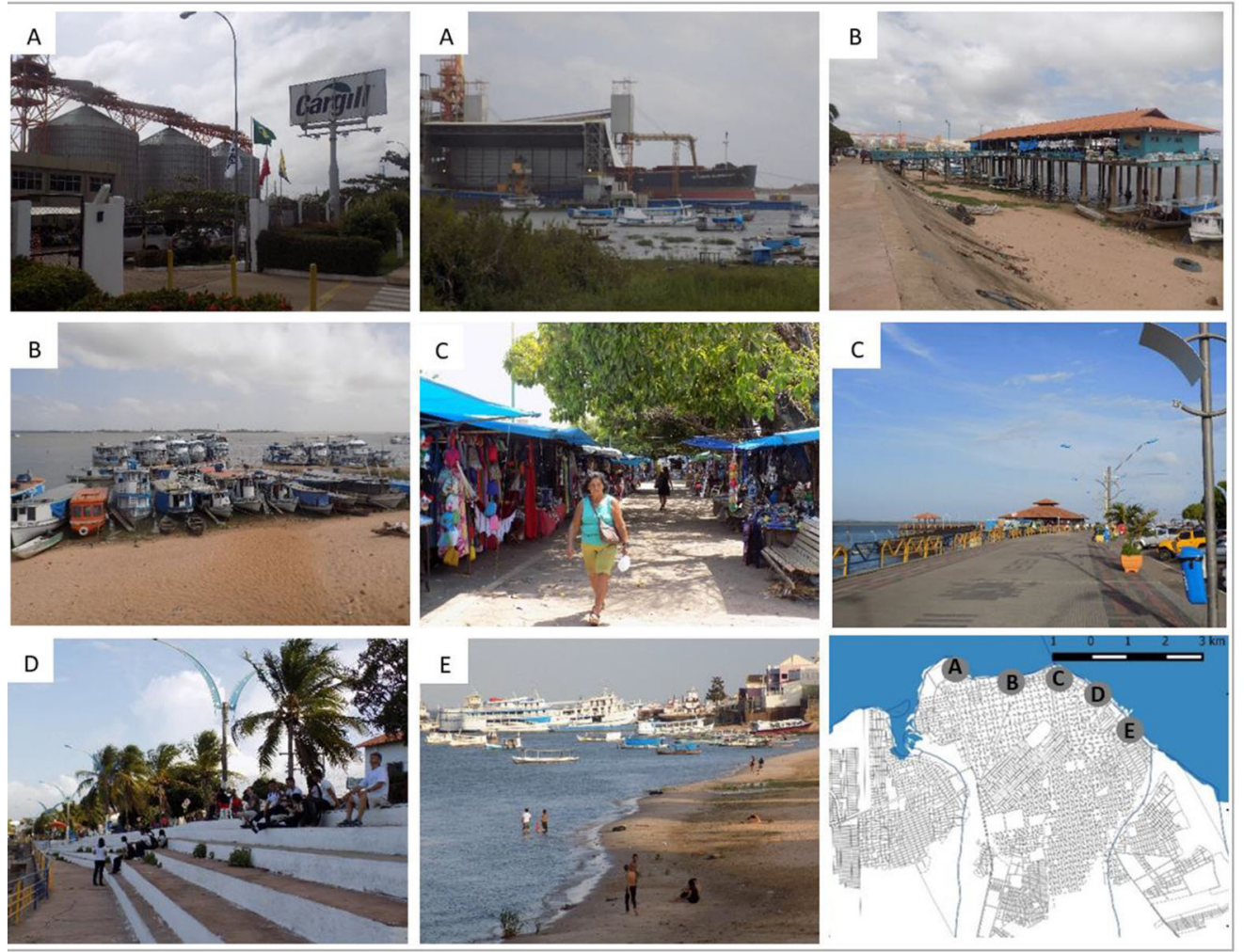

Elaboração: autores, em 2017.

luxo; e manifesta sua face amazônica, quando abriga bairros ribeirinhos em que a população depende do rio para sua sobrevivência, comunidades que dependem do trato da terra e cuja produção abastece a cidade com hortaliças e produtos da gastronomia típica da região e áreas nas quais identidades culturais e religiosos (indígenas e quilombolas) coexistem na cidade (ver Quadro 5).

As localidades dispersas que formam 0 universo "rural" têm uma relação de codependência com a malha urbana central da cidade (prestação de serviços - saúde, educação e outros), a partir das trocas dos seus produtos agrícolas e extrativistas. E, embora muitos assentamentos já existissem antes da implantação da nova logística, diante do contraste criado pelo direcionamento de investimentos para o paradigma modernizante, são interpretados como assentamentos precários, a exemplo dos espaços informais periféricos das metrópoles clássicas. A estrutura de mobilidade que dá coesão e define o pertencimento à localidade é definida pela proximidade aos eixos viários (rua, ramais, 
Quadro 5 - Diferentes racionalidades de produção do espaço urbano na cidade de Santarém. Acima: margem do rio (praia, comunidade de pescador e centro da cidade); abaixo: verticalização, shopping center e conjunto habitacional do Programa Minha Casa Minha Vida

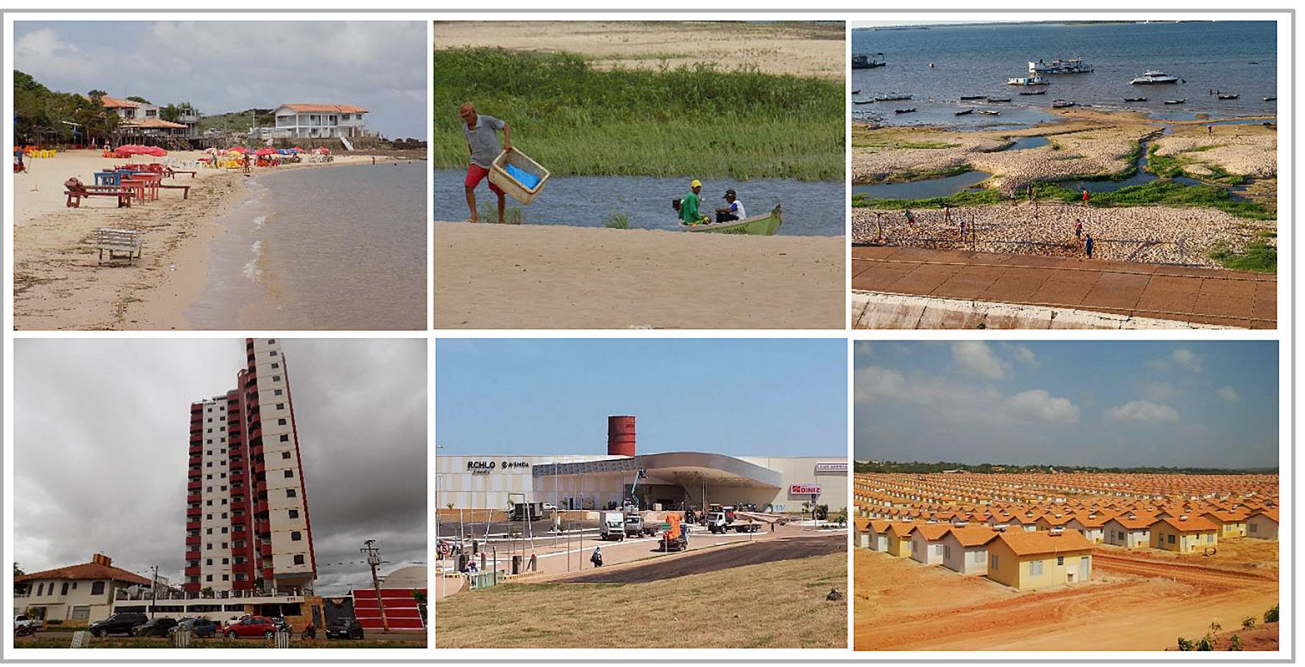

Elaboração: autores, em 2017.

rodovias, vias, estrada). As localidades tornam-se extensão da cidade e, apesar de não terem surgido a partir do padrão conhecido de periferia brasileira, formam um colar periurbano que mostra quanto o rio ou as estradas viabilizaram sua localização. Muitas localidades seculares resistem por terem sido incorporadas por áreas de assentamento criados pelo Incra, que as protegeu das mudanças de uso da terra no decorrer das últimas décadas.

A sedução do capitalismo torna a crítica a esse novo modo de produção de cidade difícil de ser reconhecida ou mesmo compreendida. As coalizões recentes, entre controladores da terra, empreendedores e o poder público (executivo e legislativo local e estadual), são pautadas por objetivos que nem sempre fazem sentido para a população mantida à margem do processo modernizante. Ao poder público, interessa a conversão à geração de tributos, não viabilizada pelas comunidades tradicionais, o que reduz seu interesse em proteger esse modo de vida e o aproxima de atores interessados na reestruturação rentável do território pela produção imobiliária. Como dito por Smith (1988), para produzir riqueza, o capitalismo precisa afastar o homem da natureza, criar concorrência no mercado, despersonalizar as pessoas, homogeneizar consumo e outros aspectos que buscam mudar a forma de vida das comunidades tradicionais e de pequenas localidades encontradas em Santarém. 
0 Quadro $6^{9}$ procura sintetizar a correlação de forças existentes no território em discussão, indicando níveis de interesse, responsabilidade, poder, tensão e omissão, manifestos pelos atores envolvidos nos setores público e privado, nos movimentos sociais e no terceiro setor ${ }^{10}$ quanto a processos de efetiva integração dos três municípios metropolitanos, crescimento e conexão das manchas urbanas, associados ao aspecto modernizador; e também ao maior ou menor respeito à biodiversidade e aos modos de vida tradicionais, associados aos interesses dessas populações. Verifica-se que a recente aproximação do governo federal do setor privado tenciona essa correlação de força em favor dos interesses capitalistas, assim como a importância do terceiro setor para o suporte de pleitos dos movimentos sociais ${ }^{11}$ (ver Figura 8).

A região que se constituía como um espaço de múltiplas determinações sob forte dependência da política estatal tenderá à conversão mais rápida, na medida em que aumenta a carência de investimentos necessários à manutenção dos modos de vida baseados no saber tradicional ou que é permitida a destruição dos recursos naturais (contaminação das águas, redução de biodiversidade, desflorestamento, etc.), transformando o que antes era a forma de se viver no lugar em estratégia de resistência (Monte-Mor, 2015).

Quadro 6 - Diagrama de correlação de forças existentes no território

\begin{tabular}{|c|c|c|c|c|c|c|c|c|c|c|}
\hline & \multicolumn{3}{|c|}{ Setor Privado } & \multicolumn{3}{|c|}{ Setor Público } & \multicolumn{2}{|c|}{ Grupos Sociais } & \multirow{2}{*}{$\begin{array}{c}\text { TerceiroSetor } \\
\text { ONGs }\end{array}$} \\
\hline & & $\begin{array}{l}\text { Proprietério } \\
\text { de terria }\end{array}$ & $\begin{array}{l}\text { Produtuor } \\
\text { imobiliario }\end{array}$ & Construtor & \begin{tabular}{|l|} 
Poder Local \\
(Legislativo \\
Executivo)
\end{tabular} & $\begin{array}{l}\text { Órgäas federais } \\
\text { (IncramMAl } \\
\text { ICMBio) }\end{array}$ & Órgäos Estaduais & STTR & $\begin{array}{l}\text { Comunidades } \\
\text { tradicionais }\end{array}$ & \\
\hline 1 & $\begin{array}{c}\text { Integracăäo } \\
\text { Metropolitana } \\
\text { Belterra - Mojui dos } \\
\text { Campos - Santarerem }\end{array}$ & 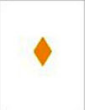 & $\bullet$ & 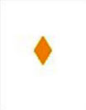 & (e) & 口 & - & 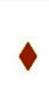 & $\triangleright$ & 口 \\
\hline 2 & $\begin{array}{l}\text { Expananão da Marcha } \\
\text { Urbana } \\
\text { (Perimetro Urbano) }\end{array}$ & - & - & $\diamond$ & (0) & 口 & $\square$ & 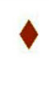 & $\diamond$ & $\bullet$ \\
\hline 3 & $\begin{array}{c}\text { Respeito à } \\
\text { Sociodiversidade }\end{array}$ & - & - & - & घ & - & - & - & - & $\checkmark$ \\
\hline 4 & $\begin{array}{l}\text { Suporte a modo } \\
\text { de vida nos } \\
\text { assentamentos } \\
\text { e comunidades } \\
\text { tradicionais }\end{array}$ & - & - & - & (0) & - & - & - & - & 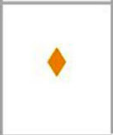 \\
\hline & LEGENDA & $\begin{array}{l}\text { Poder (a } \\
\text { - Omissão }\end{array}$ & & $\begin{array}{l}\text { Interesse } \\
\text { Interesse }\end{array}$ & & $\begin{array}{l}\text { lsão } \\
\text { n relaçăo diret }\end{array}$ & & & pressāo & \\
\hline
\end{tabular}

Elaboração: autores, em 2017. 
Figura 8 - Diferentes coalizões em disputa pelo território

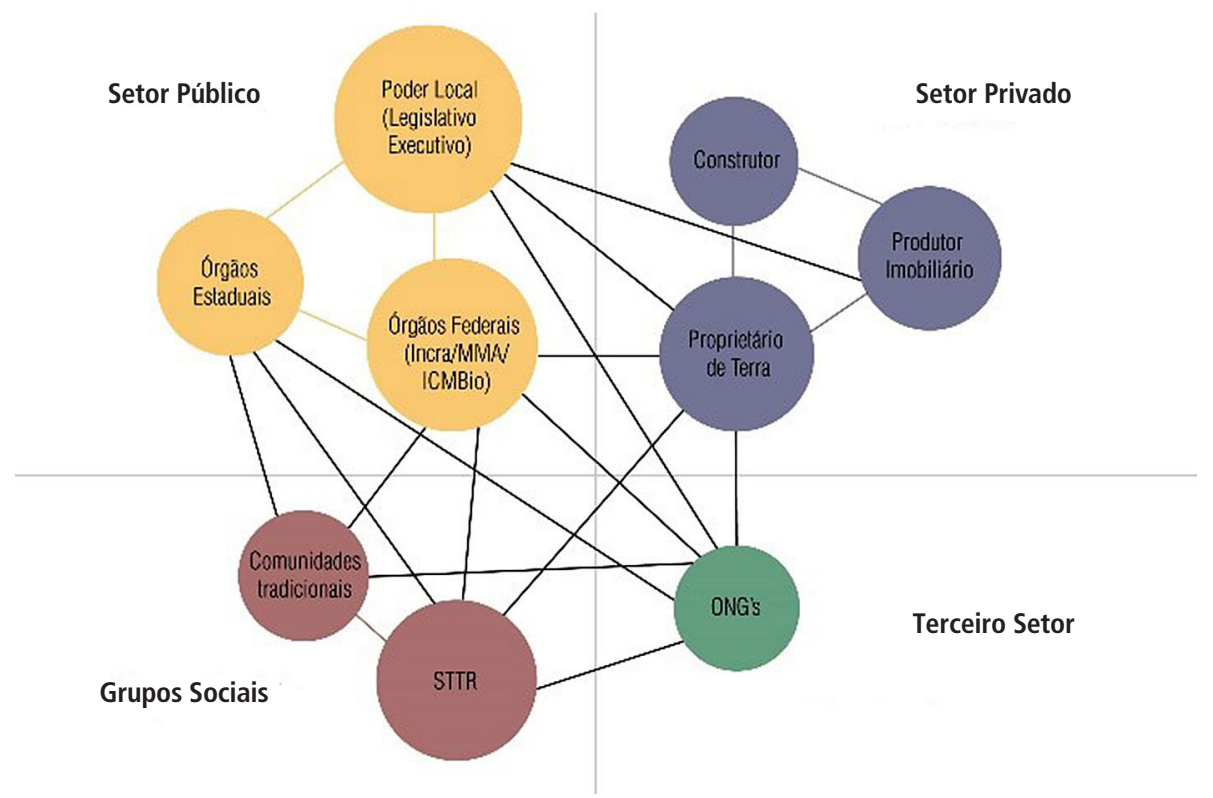

Elaboração: autores, em 2017.

A facilitação das novas leis (regularização fundiária e redução das áreas protegidas) para operação do setor privado, desde o âmbito global, torna o governo local muito vulnerável às investidas do capital industrial e financeiro, a ponto de este se colocar contra as conquistas institucionais dos grupos sociais e ambientais históricos da região. Exemplo disso é a intenção da prefeitura municipal de Santarém de questionar a existência do assentamento agroextrativista Eixo Forte na área atravessada pela estrada de acesso ao aeroporto e à vila de Alter do Chão.

A expectativa de crescimento econômico a partir das novas dinâmicas eleva o preço da terra nas áreas disponíveis para urbanização adjacentes à área urbana já consolidada, a ponto de viabilizar focos de verticalização e, de modo reverso, causando a precarização das comunidades tradicionais urbanas. A reestruturação do meio rural induz à ocupação informal de áreas urbanas ambientalmente vulneráveis, a expansão urbana formal sobre áreas de floresta, as contestações já citadas de institucionalidades vigentes por interesses imobiliários e a assimilação das vilas e localidades habitadas por comunidades tradicionais como assentamentos dormitórios.

0 conflito entre as diferentes racionalidades se manifesta em todas as esferas da vida. Contudo, apesar das transformações já ocorridas para a população vinculada à 


\section{Quadro 7 - Principais pontos do Estatuto da Metrópole}

\begin{tabular}{|c|c|}
\hline PRINCIPAIS PONTOS & RESUMO - ARCABOUÇO INSTITUCIONAL \\
\hline Aglomeração Urbana & $\begin{array}{l}\text { Unidade territorial urbana constituída pelo agrupamento de } 2 \text { (dois) ou mais municípios limítrofes, } \\
\text { caracterizada por complementaridade funcional e integração de dinâmicas geográficas, ambientais, } \\
\text { políticas e socioeconômicas }\end{array}$ \\
\hline $\begin{array}{l}\text { Função pública } \\
\text { de interesse comum }\end{array}$ & $\begin{array}{l}\text { Política pública ou ação nela inserida cuja realização por parte de um município, isoladamente, seja } \\
\text { inviável ou cause impacto em municípios limítrofes }\end{array}$ \\
\hline Gestão Plena & $\begin{array}{l}\text { Condição de região metropolitana ou de aglomeração urbana que possui: } \\
\text { a) formalização e delimitação mediante lei complementar estadual; } \\
\text { b) estrutura de governança interfederativa própria; } \\
\text { c) plano de desenvolvimento urbano integrado aprovado mediante lei estadual }\end{array}$ \\
\hline $\begin{array}{l}\text { Governança } \\
\text { interfederativa }\end{array}$ & $\begin{array}{l}\text { Compartilhamento de responsabilidades e ações entre entes da Federação em termos de organização, } \\
\text { planejamento e execução de funções públicas de interesse comum }\end{array}$ \\
\hline $\begin{array}{l}\text { Metrópole / } \\
\text { Região } \\
\text { Metropolitana }\end{array}$ & $\begin{array}{l}\text { Metrópole: espaço urbano com continuidade territorial que, em razão de sua população e relevância } \\
\text { política e socioeconômica, tem influência nacional ou sobre uma região que configure, no mínimo, } \\
\text { a área de influência de uma capital regional, conforme os critérios adotados pela Fundação Instituto } \\
\text { Brasileiro de Geografia e Estatística - IBGE. } \\
\text { Região metropolitana: aglomeração urbana que configure uma metrópole. }\end{array}$ \\
\hline Critérios & $\begin{array}{l}\text { Os critérios para a delimitação da região de influência de uma capital regional considerarão bens e } \\
\text { serviços fornecidos pela cidade à região, abrangendo produtos industriais, educação, saúde, serviços } \\
\text { bancários, comércio, empregos e outros itens pertinentes. }\end{array}$ \\
\hline Da Instituição & $\begin{array}{l}\text { Os estados, mediante lei complementar, poderão instituir regiões metropolitanas e aglomerações } \\
\text { urbanas, constituídas por agrupamento de municípios limítrofes, para integrar a organização, o } \\
\text { planejamento e a execução de funções públicas de interesse comum. }\end{array}$ \\
\hline Da Instituição & $\begin{array}{l}\text { A instituição de região metropolitana ou de aglomeração urbana que envolva municípios } \\
\text { pertencentes a mais de um estado será formalizada mediante a aprovação de leis complementares } \\
\text { pelas assembleias legislativas de cada um dos estados envolvidos. }\end{array}$ \\
\hline Da Instituição & $\begin{array}{l}\text { Até a aprovação das leis complementares por todos os estados envolvidos, a região metropolitana } \\
\text { ou a aglomeração urbana terá validade apenas para os municípios dos estados que já houverem } \\
\text { aprovado a respectiva lei. }\end{array}$ \\
\hline
\end{tabular}

Fonte: Estatuto da Metrópole, 2015.

dinâmica urbana (administração pública, comércio, serviços, produção e exportação da soja), a capacidade de atendimento dos serviços públicos é baixa, as soluções de transportes não são compatíveis com as novas distâncias, há carência de espaços verdes e públicos com infraestrutura para a sociabilidade, a prática de esporte e o lazer (produzidos sob a ótica convencional) desconsidera a oferta existente no espaço natural), demonstrando que a transição econômica tem sido mais rápida do que a socioespacial. Isso indica limitações sob a ótica da homogeneização, mas amplas oportunidades sob a ótica da diversidade e da inovação e das expectativas do bem viver em debate no norte global. 
Em meio a todas essas contradições, o processo de institucionalização da região metropolitana de Santarém é resultado da convergência de interesses nas escalas nacional, regional e municipal, e por isso foi aprovado, apesar de não existir pleno atendimento dos critérios propostos para balizar tais análises ou o devido enquadramento das condições de governança e processos em curso, a exemplo dos parâmetros criados pelo Estatuto da Metrópole (ver Quadro 7). A RM de Santarém recupera a histórica localização estratégica dos documentos federais, no que diz respeito ao escoamento da produção de grãos, a conversão de terras do extrativismo para o agronegócio e a produção da cidade alinhada à lógica da acumulação. Regionalmente, a região metropolitana de Santarém alinha-se aos antigos interesses de criação de um possível novo estado. Operacionalmente, a racionalidade da estrada e da soja ganhou força com o desmembramento do município de Mojuí dos Campos em 2010, mesmo ano em que se iniciou o processo de criação da RMS na Assembleia Legislativa do estado do Pará, concluído apenas em janeiro de 2012.

Na esfera local, a institucionalização da RM de Santarém representa o fortalecimento do poder público, com a ampliação da máquina pública, e o fortalecimento também dos interesses privados no sentido de conversão de terra rural em terra urbana e apropriação dessa terra para a maximização da mancha urbana das cidades. Desse modo, Santarém se consolida como lugar da elite local, e as cidades de Belterra e Mojuí dos Campos passam a exercer a função de periferia da RM, devido à valorização das terras em toda a RM. É clara a expulsão das classes mais pobres para as cidades vizinhas sem o fornecimento do mínimo de infraestrutura ou de serviços essenciais como 0 transporte público.

A atual legislação que regula as regiões metropolitanas do País não enxerga processos como os que estão acontecendo na cidade de Santarém que, apesar de se justificar como metrópole, apresenta uma trajetória diferente das RMs classicamente conhecidas. Essa outra trajetória precisa ser conhecida, respeitada e possivelmente protegida, pois a imposição de institucionalidades exógenas tende a viabilizar uma série de dinâmicas que exclui milhares de pessoas com modos de vida diferentes.

\section{Considerações finais}

Ao apresentar a região metropolitana de Santarém como uma região que é tocada pela dinâmica planetária, mas que também tem raízes muito bem estabelecidas nas tradições locais, este texto ilustra os processos recentes de urbanização e traz à tona outras formas de ocupação do território colocadas à margem dos processos hegemônicos, que dada a sua intensidade e enraizamento, inspiram a reflexão sobre uma estratégia de urbanização que extrapole a concepção de cidade pautada apenas pelo ponto de vista econômico ou periférico. 0 texto também destaca a importância do espaço periurbano, que não é assimilado pelo discurso dominante, e constitui-se em território sob disputa entre aqueles que já estavam estabelecidos ali originalmente- e que seguem uma estratégia de produção compatível com a preservação da floresta viva - e os atores e produtores do espaço urbano que lucram com o processo de expansão contínua e ilimitada da mancha urbana. 
Além disso, observa-se que a RM de Santarém não atende às gerações de critérios estabelecidos institucionalmente por órgãos governamentais na década de 1970 e em 2013, não apresenta o processo de conurbação nem possui políticas urbanas em comum entre os três municípios que a compõem. $A$ área urbana da RMS compreende apenas 2,36\% do território, enquanto o restante é ocupado por uma população distribuída em uma série de institucionalidades (vilas, unidades de conservação e assentamentos rurais) que indicam formas de resistência e auxílio na manutenção da população que dependem da terra e da floresta para viver. Com essas especificidades apresentadas, fica o questionamento sobre como repensar as políticas metropolitanas a fim de englobar a diversidade que compõe o mosaico da RMS, tendo em vista que as políticas existentes foram concebidas segundo parâmetros oriundos em outros contextos metropolitanos, em que há maior ênfase no espaço urbano. Se pensarmos que uma região metropolitana abrange todo o território dos municípios que a constituem e não apenas a área urbana, torna-se necessário desenvolver estratégias que diminuam as assimetrias de poder e assegurem a terra como elemento fundamental para viabilizar a vida, e não só como uma estratégia capitalista para estabelecer o que é hegemônico. Enquanto o jogo político e econômico for costurado em função de quem trata a terra como um elemento de poder, manter as institucionalidades existentes (assentamentos, Flona, Resex) e os modos de vida tradicionais pode ser interessante apenas para imobilizar a terra e a tratá-la como reserva, para quando for oportuno explorá-la ou converter seu uso, sem serem considerados como manifestação da diversidade amazônica a ser reconhecida e respeitada, a bem da preservação do próprio bioma.

Nesse sentido, a RM de Santarém apresenta-se como um espaço com grande potencial de aderência às premissas colocadas para as cidades do século XXI, pois mostra intensidade de atributos espaciais, recursos naturais, sociodiversidade e qualidades ambientais, compatíveis com o que vem sendo perseguido nos países centrais, em resposta à demanda por qualidade de vida urbana. Entretanto a região segue na contramão desse raciocínio, na medida em que reproduz as fórmulas difundidas no século anterior, convertendo sua diversidade socioespacial em espaço homogêneo voltado para produção e consumo.

Nessa perspectiva, conclui-se que ao urbano extensivo, que se estabelece a partir das determinações da ordem distante, seria possível contrapor a naturalização extensiva, por meio da preservação dos espaços naturais e do padrão de dispersão já praticados na região. Contudo, isso só será possível quando assumirmos uma postura de maior autonomia do conhecimento local para a governança daquele território, capaz de dar voz e valor ao conhecimento milenar acumulado na região. 


\section{Taynara do Vale Gomes}

Universidade Federal do Pará, Programa de Pós-Graduação em Arquitetura e Urbanismo. Belém, PA/ Brasil.

taynaragomes@gmail.com

\section{Ana Cláudia Duarte Cardoso}

Universidade Federal do Pará, Programa de Pós-Graduação em Arquitetura e Urbanismo, Programa de Pós-Graduação em Economia. Belém, PA/Brasil.

aclaudiacardoso@gmail.com

\section{Helder Santos Coelho}

Universidade Federal do Pará, Programa de Pós-Graduação em Economia. Belém, PA/Brasil. helder.coelho@yahoo.com.br

\section{Kamila Diniz Oliveira}

Universidade Federal do Pará, Faculdade de Arquitetura e Urbanismo, Laboratório Cidades na Amazônia. Belém, PA/Brasil.

kamiladinizoliveira@gmail.com

\section{Notas}

(1) Adota-se aqui o eixo espaço-temporal de urbanização da humanidade proposto por Henri Lefebvre, que situa o atual estágio da humanidade (urbano-industrial) como aquele que impõe a homogeneidade à hegemonia da técnica, da lei e do poder das elites. Além da dominação da natureza segundo a lógica do mercado (Lefebvre, 1999).

(2) A marcha para o Oeste conduzida pelo Estado Novo criou a figura dos "soldados da borracha", dentro de acordos entre Brasil e EUA, que resultaram na adaptação dos migrantes sobreviventes ao bioma e assimilação das condições de vida dos povos nativos (Ricardo, 1970).

(3) Os pedidos de lavra de minerais valiosos já registrados no DNPM, inclusive o ouro, na região de Santarém indicam que há potencial de replicação de processos já ocorridos no nordeste e sudeste paraenses portadores de conflitos socioambientais, a saber: desmatamento da floresta, expulsão e empobrecimento da população rural, redução do regime de águas, implantação de agronegócio e extrativismo mineral, intensificação da urbanização.

(4) Essa racionalidade é exposta na obra do economista Francisco Costa (Costa, 2012) que diferencia as lógicas de produção camponesa (de base extrativista) e patronal (capitalista) na região.

(5) Definida como "uma urbanização que se estende para além das cidades em redes que penetram virtualmente todos os espaços regionais, integrando-os em malhas mundiais - [que] representa, assim, a forma socioespacial dominante que marca a sociedade capitalista de estado contemporânea em suas diversas manifestações, desde o centro dinâmico do sistema capitalista até - e cada vez mais - às diversas periferias que se articulam dialeticamente em direção aos centros e subcentros e subsubcentros" (Monte-Mór, 1994, p. 171). 
(6) O ambiente periurbano é compreendido como uma zona transicional ou zona de interação, onde atividades urbanas e rurais estão justapostas e características da paisagem estão sujeitas à rápida mudança, levando a transformações nos sistemas hidrológicos, ecológico, geomorfológico e socioeconômico, sendo frequentemente negligenciadas pelas administrações tanto rurais como urbanas (Douglas, 2006, p. 18).

(7) Destaque para um loteamento chamado Vila Planalto, construído a cerca de 15 km de Santarém em meio à área de plantação de soja, ocupado por casas de alto padrão construtivo, comercializadas a preços semelhantes aos das grandes cidades, ocupados por migrantes que consideravam que a cidade não contava com áreas habitacionais compatíveis com suas necessidades, mas que, após a difusão dos malefícios dos agrotóxicos para a saúde da população, passaram a vender suas casas e a se dirigir para os novos empreendimentos habitacionais localizados na cidade de Santarém.

(8) A esse respeito são dignos de nota os recentes movimentos do governo federal de redução das áreas indígenas, de áreas de preservação, de condições de licenciamento e de regularização fundiária propostos pelas MPs 756, 758 e 759 que têm sido aprovadas a toque de caixa pelo Congresso Nacional, tendo em vista a sua rápida conversão em leis que alteram décadas de acordos e conquistas do povo brasileiro.

(9) Adaptação do Diagrama de poder desenvolvido por Mcglynn (1993) e aplicado ao contexto amazônico por Cardoso (2007).

(10) Na década de 1990, a literatura internacional (Burgess, Carmona e Kolstee, 1997) apontava a correlação de forças entre esses setores como estratégica para compensar a redução do Estado, apregoada pelo neoliberalismo. E talvez o suporte de ONGs, tais como o Ipam, Saúde Alegria, Fase Amazônia, tenha sido decisivo para a interlocução entre movimentos sociais e setor público. No novo desenho, o setor privado tem sido beneficiado pelo realinhamento do setor público em geral.

(11) Durante a pesquisa de campo, foram realizadas entrevistas em órgãos do setor público, sindicatos e ONGs, que relataram um movimento de revogação de demarcações institucionais (Incra e Interpa) que asseguram a terra para manutenção de modos de vida tradicionais.

\section{Referências}

BECKER, B. (1998). Amazônia. São Paulo, Ática.

BRASIL Constituição (1967). Parágrafo 10 do artigo 157 da Constituição Federativa do Brasil. Brasília, DF, Senado Federal.

BRASIL (1973). Lei Complementar n. 14, de 8 de junho de 1973. Estabelece as regiões metropolitanas de São Paulo, Belo Horizonte, Porto Alegre, Recife, Salvador, Curitiba, Belém e Fortaleza. Diário Oficial [da] República Federativa do Brasil.

BRASIL - Presidência da República (2015). Lei no 13.089, de 12 de janeiro de 2015. Institui o Estatuto da Metrópole. Brasília. 
BURGESS, R., CARMONA, M. e KOLSTEE, T. (1997). “Contemporary macroeconomic strategies and urban policies in developing countries: a critical review". In: BURGESS, R., CARMONA, M. e KOLSTEE, T. (orgs.). The challenge of sustainable cities. Londres, Zed Books.

CARDOSO, A. C. (2007). O espaço alternativo: vida e forma urbana nas baixadas de Belém. Belém, EDUFPA.

CARLOS, A. F. (2015). A virada espacial. Revista Mercator. Fortaleza, v. 14, n. 4, pp. 7-16.

CASTELLO BRANCO, M. et al. (2013). Rediscutindo a delimitação das regiões metropolitanas no Brasil: um exercício a partir dos critérios da década de setenta. Rio de Janeiro, Ipea.

CASTELLS, M. (1999). A sociedade em rede. São Paulo, Paz e Terra.

COSTA, F. A. (2012). Elementos para uma economia política da Amazônia. Belém, NAEA.

COSTA, M. e TSUKUMO, I. (2013). 40 anos de regiões metropolitanas no Brasil. Brasília, Ipea.

DOUGLAS, I. (2006). "Peri-urban ecosystems and societies: transitional zones and contrasting values". In: MACGREGOR, D.; SIMON, D. e THOMPSON, D. (orgs.). The Peri-Urban Interface. Londres, Earthscan.

EMATER (2011). Plano de desenvolvimento do Assentamento Eixo Forte. Empresa de assistência técnica e extensão rural. Santarém.

EUCLYDES, A. C. P. (2016). A hipótese otimista: dialética e utopia das áreas verdes, das áreas protegidas e da trama verde e azul. Tese de Doutorado. Belo Horizonte, Universidade Federal de Minas Gerais.

FAMCEEF (2007). Estatuto da Famceef. Santarém, Federação das associações de moradores, comunidade e entidades do assentamento agroextrativista Eixo Forte.

GALVÃO, M. V. et al. (1969). Áreas de Pesquisa para Determinação de Áreas Metropolitanas. Revista Brasileira de Geografia, v. 31, n. 4, pp. 53-140.

GARSON, S. (2009). Regiões Metropolitanas: por que não cooperaram? Rio de Janeiro, Letra Capital.

HAAS, T. et al. (2012). Sustainable urbanism and beyond: rethinking cities for the future. Nova York, Rizzoli.

HALL, P. (1995). Cidades do amanhã. São Paulo, Perspectiva.

HARVEY, D. (2016). 17 contradições e o fim do capitalismo. São Paulo, Boitempo.

LEFEBVRE, H. (1999). A revolução urbana. Belo Horizonte, Editora da UFMG.

(2008). Espaço e política. Belo Horizonte, Editora da UFMG.

LEITE, M. (2009). A floresta Amazônica. São Paulo, Publifolha.

MARICATO, E. (2001). Brasil, cidades: alternativas para a crise urbana. Petrópolis, Vozes.

MARTÍNEZ, Z. (2012). Postsuburbia. Barcelona, Comanegra.

MCGLYNN, S. (1993). "Reviewing the rhetoric". In: HAYWARD, R. e MCGLYNN, S. (orgs.). Making better places: urban design now. Londres, Betterworth.

MENERAULT, P. (2014). Implantação de trama verde-azul no Bacia Mineira no Nord-Pás de Calais na França. In: SEMINÁRIO METROPOLITANO DO MACROZONEAMENTO DA REGIÃO METROPOLITANA DA GRANDE BH. Anais... Belo Horizonte, UFMG. 
MONTE-MÓR, R. (1994). “Urbanização extensiva e lógicas de povoamento: um olhar ambiental”. In: SANTOS, M. et al. (orgs.). Território, globalização e fragmentação. São Paulo, Hucitec.

(2015). “Urbanização, Sustentabilidade, Desenvolvimento: complexidades e diversidades contemporâneas na produção urbano". In: COSTA, G., COSTA, H. e MONTE-MÓR, R. (orgs.) Teorias e práticas urbanas: condições para a sociedade urbana. Belo Horizonte, C/Arte.

NEVES, W. (1992). Origens, adaptações e diversidade biológica do homem nativo da Amazônia. Belém, Museu Paraense Emílio Goeldi.

RICARDO, C. (1970). A marcha para o oeste. Rio de Janeiro, José Olympio.

ROOSEVELT, A. C. (1992). “Arqueologia Amazônica”. In: CARNEIRO DA CUNHA, M. (org.). História dos índios no Brasil. São Paulo, Companhia das letras.

SANTARÉM (2006). Lei n. 18.051, de 29 de dezembro de 2006. Institui o Plano Diretor Participativo do Município de Santarém. Diário Oficial do Municiípio de Santarém. Santarém, PA, 29 dez 2006.

SANTOS, M. (1979). O espaço dividido. São Paulo, Francisco Alves.

(2013). O trabalho do geógrafo no terceiro mundo. São Paulo, Edusp.

SASSEN, S. (1988). O lugar e a produção na economia global. As cidades na economia mundial. São Paulo, Studio Nobel.

SMITH, N. (1988). Desenvolvimento desigual. Rio de Janeiro, Bertrand Brasil.

SOUZA, A. (2016). Economia e natureza: padrões de uso e cobertura da terra associados a atividades agropecuárias e extrativistas de comunidades do sudoeste do Pará. Dissertação de Mestrado. São José dos Campos, Instituto Nacional de Pesquisas Espaciais.

TAVARES, H. (1986). Políticas de desenvolvimento regional nos países do "centro" e no Brasil. Cadernos Ippur/UFRJ. Rio de Janeiro, ano 1, n. 1.

Texto recebido em 30/maio/2017

Texto aprovado em 24/ago/2017 